\title{
Cassava as an insurance crop in a changing climate: The changing role and potential applications of cassava for smallholder farmers in Northeastern Thailand
}

\author{
Anan Polthanee ${ }^{1, *}$ \\ ${ }^{1}$ Program on System Approaches in Agriculture, Faculty of Agriculture, Khon Kaen University, Thailand. \\ E-mail: panan@kku.ac.th \\ * Corresponding author
}

\begin{abstract}
Approximately 80 percent of the 22 million people in Northeastern Thailand are engaged in agriculture, and the per capita income of the region is lower than in any other part of Thailand. The major constraint to crop production is rainfall. Although the region has an average annual rainfall greater than 1200 $\mathrm{mm}$, the seasonal distribution of rainfall makes for challenging agricultural cultivation opportunities. The climate is characterized by rainy (May-October) and dry (November-April) seasons. Most (90\%) farming is cultivated under rainfed conditions. In addition, most soils are characterized by a sandy texture, high acidity, low organic matter, low level of plant nutrients and low water holding capacity. Due to these conditions, and an increasingly unpredictable climate horizon, cassava has come to play an important economic role for smallholder farmers in the region. The inherent tolerance of cassava to stressful environments, requires minimal care, less investment, and provides greater flexibility in planting and harvesting. Although cassava is grown as a monoculture crop, it can also be grown profitably as a second crop in rice-based cropping systems without supplemental irrigation during the dry season, as well as intercropped in rubber plantations at early growth stages. Given the importance of cassava in farmer income, export values, marketing, and labor, this paper discusses the broader socio-economic and biophysical aspects of cassava due to its important role in future agrarian change for the region.
\end{abstract}

Keywords: Cassava; stakes-soaking; double-cropping; intercropping; socioeconomics of smallholders; agrarian change; climate change; Thailand

\section{Introduction}

Thailand is divided into four regions (Northern, Northeastern, Central Plain and the Southern region) and in each region agriculture is the main occupation. It plays an important role in the economic development of the country. The Northeastern region consists of one-third of the total population ( 22 millions) and approximately one-third of the total land area (17 million hectares) of the whole country (Department of Provincial Administration, 2016). However, household income in the Northeast is the lowest (US\$ 7,194) while the Central Plain is the highest (US\$14,504) (Office of Agricultural Economics, 2017). This gap is largely due to the region being drier than that of other regions, thus providing less agricultural opportunities. Furthermore, irrigated areas is available for only $18 \%$ of the whole region (Royal Irrigation Department, 2008). Most of the soils are infertile and have poor moisture retention capacity (Noble, 2005).

The purpose of this research is to examine the description of the general topography, climate and soil of Northeastern Thailand. Special attention is devoted to cassava production trends, crop adaptation to drought stress, low input production and some economic performance such as labor, income and marketing in order to provide a synopsis of the role of cassava for smallholder farmers in Northeastern Thailand. These findings highlight that cassava will continue to play an 
important role in future agricultural systems of the region.

\section{Physical conditions in the Northeastern Region}

\subsection{Topography}

The landscape is predominantly characterized by a gently sloping to undulating landform. Upland areas located in the top of sloping, while the lowland area presented in the bottom of sloping. Main crops grown in the upland areas are cassava, sugarcane, and maize. The lowland areas generally have alluvial soils that are suitable for rice cultivation. About 750,503 ha of the upland areas is devoted to cassava (Office of Agricultural Economics, 2018). In general, cassava is suitable to cultivation in a gently sloping landform. Cassava has been grown for many years as an insurance crop for many of the smallholder farmers of the rural population in Northeastern Thailand, and this increasingly true under more recent variability with global warming. Since, cassava is particularly well adapted to drought. However, some farmers have also elected to switch their cassava crops to focus on rubber tree plantations in the last ten years, due to rubber tree provided higher cash income than that of cassava.

\subsection{Climate}

Northeastern Thailand has a semi-humid tropical climate which is characterized by rainy (May-October) and dry (November-April) seasons (Goto et al., 2008). There is a distinct rainy season from May to October that exhibits a bimodal pattern with a first peak in May to June and the second in July to October (Polthanee, 1990). Average annual rainfall varies from 1,200 mm to 1,500 mm, based on isohytes (Lacombe et al. 2017). The critical climatic factor affecting agriculture however, is the extreme variability of rainfall both within a year and between years, rather than the total amount of rainfall.

The year can be divided into three seasons. This includes the rainy season that begins in May and ends in October. The winter season that starts in November through January, and the dry season that begins from February to the end of April. Climate is the primary factor for agricultural production. Due to climate changes in the past decade, the beginning of rainy season has experienced increased variability (Atichart et al., 2013). Mean annual rainfall increased $66 \mathrm{~mm}$ when comparing the periods 1981-1996 and 1997-2012 (Polthanee and Promkhambut, 2014). Changes in temperature also increased between the maximum and minimums in Northeastern Thailand as has been reported by Polthanee and Promkhambut (2014). The mean maximum temperature increased in the rainy season $\left(0.25^{\circ} \mathrm{C}\right)$ and winter season $\left(0.89^{\circ} \mathrm{C}\right)$, and the mean minimum temperature in the rainy season also increased $\left(0.33^{\circ} \mathrm{C}\right)$, as well as the winter season $\left(1.33^{\circ} \mathrm{C}\right)$ when comparing the periods between 1981-1996 and 1997-2012 (Polthanee and Promkhambut, 2014). These climatic changes resulted in greater risk for farming ventures in recent year due to the increased temperature and highly variable rainfall pattern.

\subsection{Soil}

Northeastern Thailand soil consist of nine sub-orders: Usterts, Aquepts, Tropepts, Ustolis, Aqualfs, Aquults, Ustults and Udults (Survey Division, 1996). Ustults area is the largest and mainly used for field crops. Aquults areas is flat and mainly used for paddy rice (Tongpoonpol et al., 2012). The soil texture is characterized by sandy or sandy loam to sandy clay loam with low organic matter content, low cation exchange capacity, low level of plant nutrients and acid reaction (Idhipong et al., 2012). In general, cassava provides a higher yield on light loams (Wilson, 1997). However, cassava is extremely tolerant to acid soil, growing well even at a pH as low as 4.2-4.5 and at $75-80 \%$ Al saturation (Howeler, 2002). 


\section{Cassava in Northeastern}

\subsection{Cassava production trends}

Cassava planted areas vary year by year depending heavily on favorable cassava prices compared to those of competing crops, especially sugarcane. However, cassava planted areas in Northeastern Thailand was stable at around 739,000 hectares since 2015 (Figure 1).

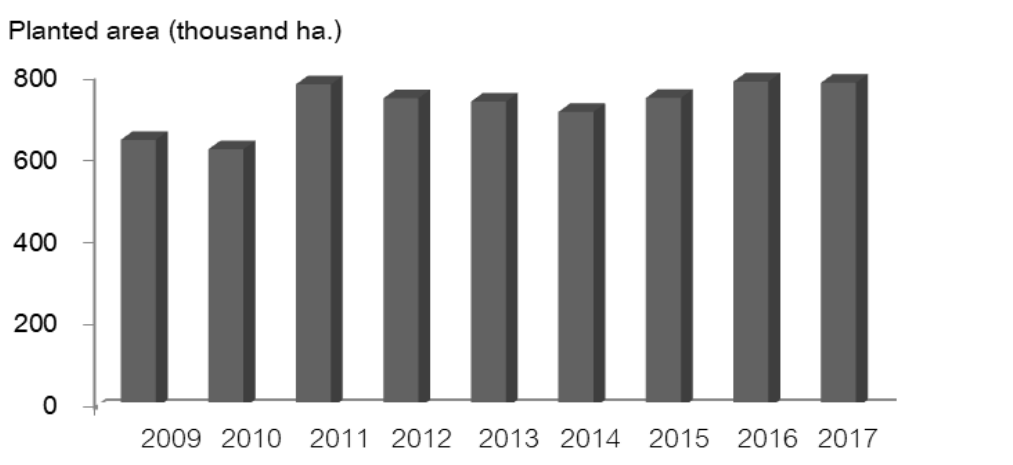

Source : Office of Agricultural Economics (2017)

Figure 1. Cassava planted area of northeastern Thailand

\subsection{Cassava as an insurance crop}

Sugarcane provides higher cash income than cassava. The farmers who grow sugarcane must receive a certain quota of planting areas from the factory. Sugarcane will be harvested for sale only during the period of sugar factory operation. For cassava, farmers are able to harvest and sell any time during the year and it is increasingly becoming an important source of cash income for smallholder farmers. As noted in the biophysical sections above, cassava is a drought tolerant crop and has a great ability to survive under uncertain rainfall patterns (Cock, 1985; El-sharkawy, 1993). In addition, cassava is tolerant to acidic soil conditions and it can grow on poor soils (FAO, 2010; De Tafur et al., 1997).

\subsection{Cassava requires minimal care and less investment}

In general, cassava production is not seriously affected by insect and diseases damage in Northeastern Thailand. However, pests can cause yield losses if the crop is not adequately weeded during the early stages of plant growth, especially near the cassava planting date in the late rainy season. Weed competition can be reduced by planting in the late rainy season when weed growth is less vigorous. Therefore, most farmers switched from planting in the early rainy season to the late rainy season to solve the weed problem. In general, one hand weeding done at one month after planting is recommended for weed control before canopy closure.

Planting material is one of the advantageous aspects of reducing production cost. Cassava is normally planted using stem cuttings, also called "stakes". The stems are cut when the mother plant is 8-12 months old. In general, farmers use stem cuttings from their fields after harvest in the previous season as planting material.

\subsection{The long stem cutting storability of cassava before planting}

After cassava harvest, farmers keep the stem by placing it under the shade of a tree and wait for long periods of time before having to plant. Cassava stems, even when stored for longer than 2-3 months, can help to wait for conditions of sufficient rainfall and soil moisture. The cutting 
stems $(15-20 \mathrm{~cm})$ had little effect on germination percentage and sprouting rate. Polthanee (2018) found that stems placed under a tree for 2 months retain stake moisture (50-55\%) and still produced high germination percentage (83-100\%), depending on cassava cultivars. Furthermore, cassava cutting stems from mother plants stored for 3 months experienced stake moisture reduction of 40 $47 \%$ at planting and decreased germination percentage (50-67\%), depending on cassava cultivars. Due to the capability of stem cuttings from mother plants to store for longer time with little effect on germination percentage, farmers can wait for adequate soil moisture conditions for planting in the event of delays in rainfall conditions in the upcoming season (see Figure 2)".
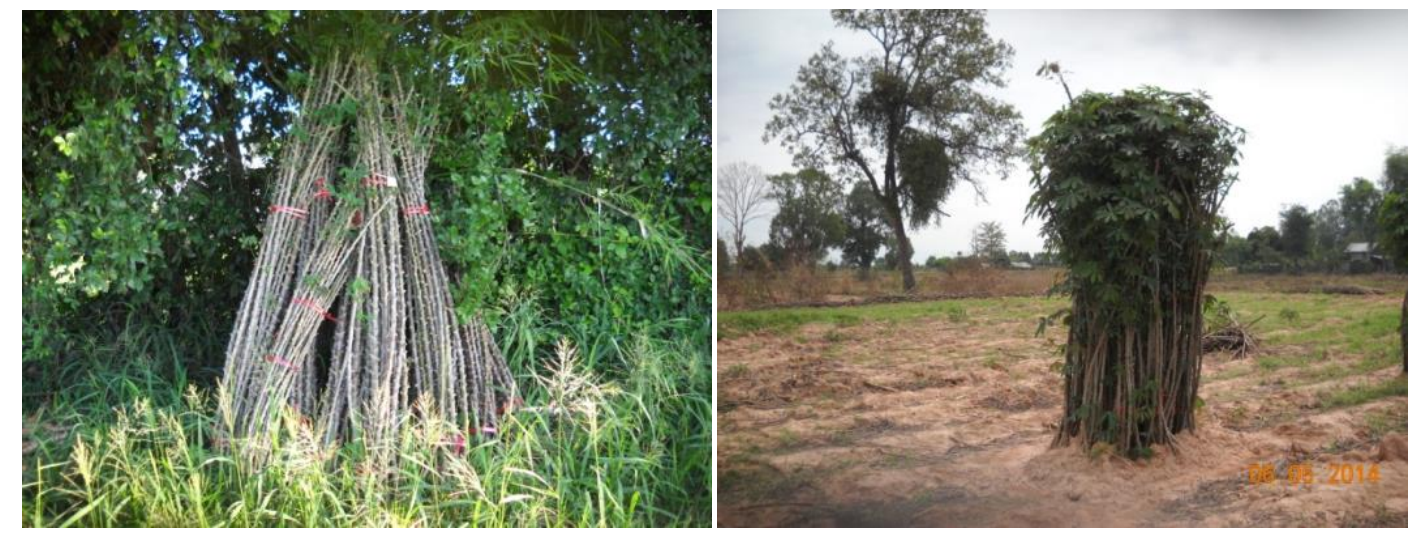

Figure 2. Cuttings of mother stem stored by farmers before planting, Northeast Thailand

\subsection{Low investment of improving cassava stakes viability}

As described previously, the cassava stem cuttings from mother plants stored for 3 months retain stake moisture of $40-47 \%$ and experience a reduced germination percentage by $50-67 \%$. These rates can also further be improved by soaking stakes before planting. Polthanee (2008) observed that stakes were soaked in water or $10 \mathrm{gm}$ of urea diluted in 5 liters of water for 1 hour and resulted in improved germination percentages from $50-67 \%$ to $90-100 \%$, depending on cultivars. The stakes that received sufficient carbohydrate enables plants to retain vigor for a longer period even under adverse conditions like drought (Nedunchezhiyan et al., 2006)

Table 1. Effect of soaking stakes in chitosan and wood vinegar solutions at different concentration rates on early growth ( 21 days after planting) of cassava

\begin{tabular}{lllll}
\hline Treatment & $\begin{array}{l}\text { Leaf area } \\
\text { (cm²/plant) }\end{array}$ & $\begin{array}{l}\text { Stem dry weight } \\
\text { (gm/plant) }\end{array}$ & $\begin{array}{l}\text { Root length } \\
\text { (cm/plant) }\end{array}$ & $\begin{array}{l}\text { Root dry weight } \\
\text { (gm/plant) }\end{array}$ \\
\hline $\begin{array}{l}\text { Bio-activator across concentration (B) } \\
\text { Chitosan }\end{array}$ & 283.9 & 0.46 & & \\
Wood vinegar & 250.2 & 0.38 & $1358.0 \mathrm{a}$ & 0.31 \\
$\quad$ Nil-soaking & 229.5 & 0.34 & $980.2 \mathrm{ab}$ & 0.26 \\
$\begin{array}{l}\text { Concentration across bioactivator (C) } \\
5 \text { cc }\end{array}$ & 229.4 & 0.34 & $934.4 \mathrm{~b}$ & 0.25 \\
$10 \mathrm{cc}$ & 283.9 & 0.40 & $723.5 \mathrm{~b}$ & $0.18 \mathrm{~b}$ \\
$15 \mathrm{cc}$ & 250.2 & 0.46 & $1488.0 \mathrm{a}$ & $0.32 \mathrm{a}$ \\
\hline F-test & & & $1061.2 \mathrm{ab}$ & $0.26 \mathrm{ab}$ \\
B & $\mathrm{ns}$ & $\mathrm{ns}$ & $*$ & $\mathrm{~ns}$ \\
$\mathrm{C}$ & $\mathrm{ns}$ & $\mathrm{ns}$ & $*$ & $*$ \\
B x C & $\mathrm{ns}$ & $\mathrm{ns}$ & $\mathrm{ns}$ & $\mathrm{ns}$ \\
\hline
\end{tabular}

ns $=$ Not significant, ${ }^{*}$ Significantly different at $P \leq 0.05$. Mean in the same column with different letters are significantly at $P \leq 0.05$ by LSD. Source: Adapted from Polthanee and Bamrungrai (2016) 
The stakes viability can be improved by soaking in chitosan (10 cc diluted in 10 liters of water) for enhancing shoot and root growth at early growth stages (Table 1). This was due to chitosan induced photochemical process of the plant and result in more vigorous growth (Reddy et al., 1999).
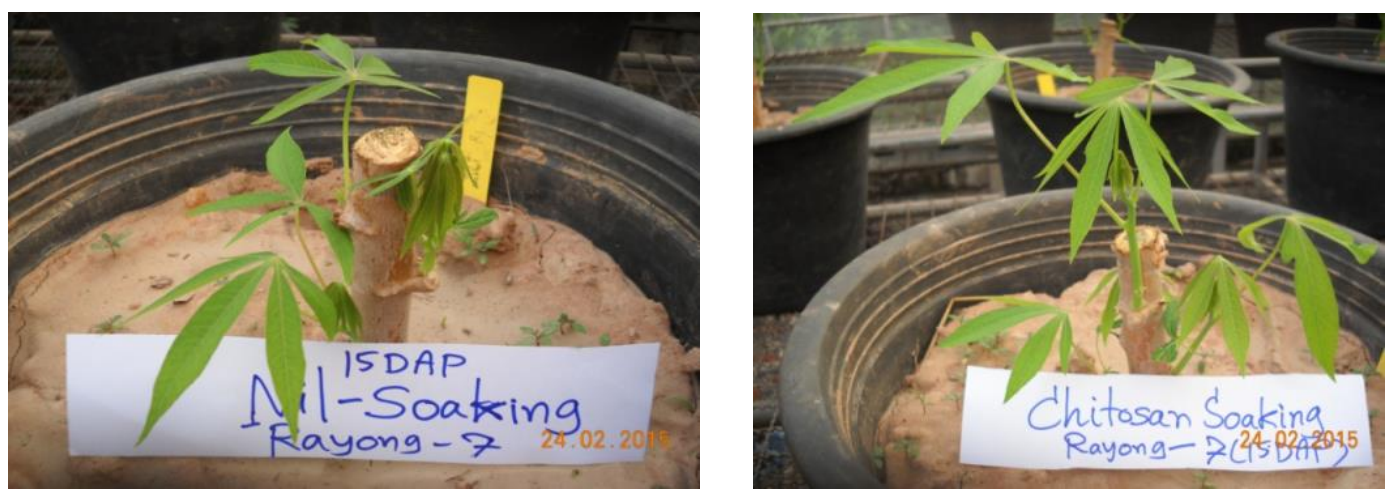

Figure 3. Comparison of soaking stakes (chitosan) and nil-soaking at early growth stage of cassava, greenhouse experiment

Cassava stakes germination practices and early growth conditions also influence nutritional content. Polthanee and Manuta (2015) studied the effect of nutrition content of stakes on early growth of cassava. They reported that high nutritional content (total $\mathrm{N}=0.386 \%$, total $\mathrm{P}=0.110 \%$, total $\mathrm{K}=2.648 \%$ ) provided for higher plant growth rates than those of low nutritional content (total $\mathrm{N}=0.274 \%$, total $\mathrm{P}=0.091 \%$, total $\mathrm{K}=1.115 \%$ ) (Table 2). Similar findings were reported by Molina and El-Sharkawy (1995).

Table 2. Effect of stakes nutritional content and soaking of different nutrient solution on early growth ( 21 days after planting) of cassava

\begin{tabular}{|c|c|c|c|c|}
\hline Treatment & $\begin{array}{l}\text { Fine root } \\
\text { (no./plant) }\end{array}$ & $\begin{array}{l}\text { Fine root } \\
\text { fresh weight } \\
\text { (gm/plant) }\end{array}$ & $\begin{array}{l}\text { Sprouting } \\
\text { (no./plant) }\end{array}$ & $\begin{array}{l}\text { Shoot } \\
\text { fresh weight } \\
\text { (gm/plant) }\end{array}$ \\
\hline \multicolumn{5}{|c|}{ Nutritional status across nutrient soaking (N) } \\
\hline High & $32.3 \mathrm{a}$ & $5.8 \mathrm{a}$ & $5.1 \mathrm{a}$ & $5.4 \mathrm{a}$ \\
\hline Low & $15.6 \mathrm{~b}$ & $1.9 \mathrm{~b}$ & $3.3 \mathrm{~b}$ & $1.9 \mathrm{~b}$ \\
\hline \multicolumn{5}{|c|}{ Nutritional soaking across nutritional status (S) } \\
\hline $\mathrm{N}$ solution & 21.9 & $2.9 \mathrm{~b}$ & 4.3 & $2.9 a b$ \\
\hline P solution & 28.1 & $5.5 \mathrm{a}$ & 3.4 & $5.2 \mathrm{a}$ \\
\hline $\mathrm{N}+\mathrm{P}$ solution & 24.4 & $4.9 \mathrm{a}$ & 4.9 & $3.8 \mathrm{ab}$ \\
\hline Nil-soaking & 21.5 & $2.2 \mathrm{~b}$ & 4.1 & $2.6 \mathrm{~b}$ \\
\hline \multicolumn{5}{|l|}{ F-test } \\
\hline $\mathrm{N}$ & $* *$ & ** & $* *$ & $* *$ \\
\hline$S$ & ns & $* *$ & ns & $*$ \\
\hline $\mathrm{N} \times \mathrm{S}$ & ns & ns & ns & ns \\
\hline
\end{tabular}

ns $=$ Not significant, Significantly different at $P \leq 0.05\left({ }^{*}\right)$ and $P \leq 0.01\left(^{* *}\right)$

Mean in the same column with different letters are significantly at $P \leq 0.05$ by LSD.

Source: Adapted from Polthanee and Manuta (2015) 


\subsection{Cassava as a drought-tolerant crop}

In general, cassava can withstand significant periods of drought stress. Mechanisms of drought tolerance in cassava have been identified such as partial stomatal closure to reduce transpiration (El-shaarkawy and dock, 1984; Alves and Setter, 2000), reduction in leaf canopy (Connor and Cock, 1981; Ike and Thurtell, 1981, Polthanee et al., 2016a) and extensive root systems (El-sharkawy, 2007). Farmers normally practice two planting times under rainfed conditions in Northeast Thailand. Cassava planting in the early rainy season will be exposed to prolonged drought at late growth stages, while planting during the late rainy season will be subjected to drought at an early growth stage.

Climate conditions in the Northeast as detailed above are characterized by rainy (MayOctober) and dry (November-April) seasons. Cassava is harvested at 8-12 months. Polthanee et al. (2016) studied growth and yield of different cassava cultivars grown in the early rainy season under rainfed conditions. They reported that cassava cultivars had a significant effect on tuber yield. The maximum tuber yield was obtained in Rayong-7 cultivars, but did not experience a significant difference with Rayong-72 and Huaybong-80 cultivars (Table 3). This indicates that the three cultivars adapted to water stress at late growth stages better than Rayong-11 cultivar.

Table 3. Growth and yield of four cassava cultivars planted in the early rainy season (2013-2014) of Northeast Thailand under rainfed conditions

\begin{tabular}{lllll}
\hline Cultivar & $\begin{array}{l}\text { Leaf dry weight } \\
\text { (t/ha) }\end{array}$ & $\begin{array}{l}\text { Stem dry weight } \\
\text { (t/ha) }\end{array}$ & $\begin{array}{l}\text { Storage root } \\
\text { (no./plant) }\end{array}$ & $\begin{array}{l}\text { Yield } \\
\text { (t/ha) }\end{array}$ \\
\hline Rayong-7 & $4.94 \mathrm{a}$ & 3.65 & 12.90 & $33.70 \mathrm{a}$ \\
Rayong-11 & $3.86 \mathrm{ab}$ & 4.86 & 11.20 & $20.30 \mathrm{~b}$ \\
Rayong-72 & $2.83 \mathrm{~b}$ & 2.69 & 11.30 & $29.40 \mathrm{ab}$ \\
Huaybong-80 & $3.69 \mathrm{ab}$ & 4.29 & 12.50 & $27.60 \mathrm{ab}$ \\
\hline F-test & $*$ & $\mathrm{~ns}$ & $\mathrm{~ns}$ & $*$ \\
CV (\%) & 21.2 & 33.3 & 14.3 & 20.1 \\
\hline
\end{tabular}

ns $=$ Not significant, ${ }^{*}$ Significantly different at $P \leq 0.05$.

Mean in the same column with different letters are significantly at $P \leq 0.05$ by LSD.

Source: Adapted from Polthanee et al. (2016a)

Polthanee and Wongpichet (2017) studied the effect of planting methods and cassava varieties on tuber yield and starch content of cassava grown in the late rainy season under rainfed conditions. They stated that vertical planting methods (stakes inserted vertically into the soil on top of ridges) gave significantly higher tuber yields than those of stakes planted horizontally (making a long furrow on top of ridges and laying the stakes down and covering with soil) (Table 4). The Rayong-7 variety gave the highest tuber yield but without significant differences in comparison to Rayong-11, Huagbong-80 and E-dum varieties (Table 4). 
Table 4. Effect of planting methods and cultivars on yield and starch content of cassava planted in the late rainy season (2014-2015) of northeastern Thailand under rainfed canditions

\begin{tabular}{|c|c|c|c|c|}
\hline Treatment & $\begin{array}{l}\text { Storage root } \\
\text { (no./plant) }\end{array}$ & $\begin{array}{l}\text { Weight storage root } \\
\text { (kg/plant) }\end{array}$ & $\begin{array}{l}\text { Yield } \\
\text { (t/ha) }\end{array}$ & $\begin{array}{l}\text { Starch content } \\
(\%)\end{array}$ \\
\hline \multicolumn{5}{|c|}{ Planting method across cultivars (M) } \\
\hline Vertical & $10.7 \mathrm{a}$ & 6.1 & $60.6 \mathrm{a}$ & 28.1 \\
\hline Horizontal & $8.9 b$ & 5.3 & $54.3 \mathrm{~b}$ & 27.8 \\
\hline \multicolumn{5}{|c|}{ Cultivar across planting methods (C) } \\
\hline Rayong-7 & $10.3 \mathrm{a}$ & $6.7 \mathrm{a}$ & $67.4 \mathrm{a}$ & $28.5 \mathrm{ab}$ \\
\hline Rayong-11 & $10.8 \mathrm{a}$ & $5.4 a b$ & $54.6 \mathrm{ab}$ & 28.9 a \\
\hline Rayong-72 & $7.7 \mathrm{~b}$ & $5.3 a b$ & $49.7 \mathrm{~b}$ & $26.4 \mathrm{~b}$ \\
\hline Huaybong-80 & $10.1 \mathrm{ab}$ & $4.8 \mathrm{~b}$ & $55.0 \mathrm{ab}$ & 29.4 a \\
\hline E-dum & $10.2 \mathrm{a}$ & $6.1 \mathrm{ab}$ & $60.4 a b$ & $26.6 \mathrm{~b}$ \\
\hline \multicolumn{5}{|l|}{ F-test } \\
\hline M & $*$ & ns & $*$ & ns \\
\hline C & $*$ & $*$ & $*$ & $*$ \\
\hline $\mathrm{M} \times \mathrm{C}$ & ns & ns & ns & $*$ \\
\hline
\end{tabular}

ns $=$ Not significant, Significantly different at $P \leq 0.05\left({ }^{*}\right)$ and $P \leq 0.01\left(^{* *}\right)$

Mean in the same column with different letters are significantly at $P \leq 0.05$ by LSD.

Source: Adapted from Polthanee and Wongpichet (2017)
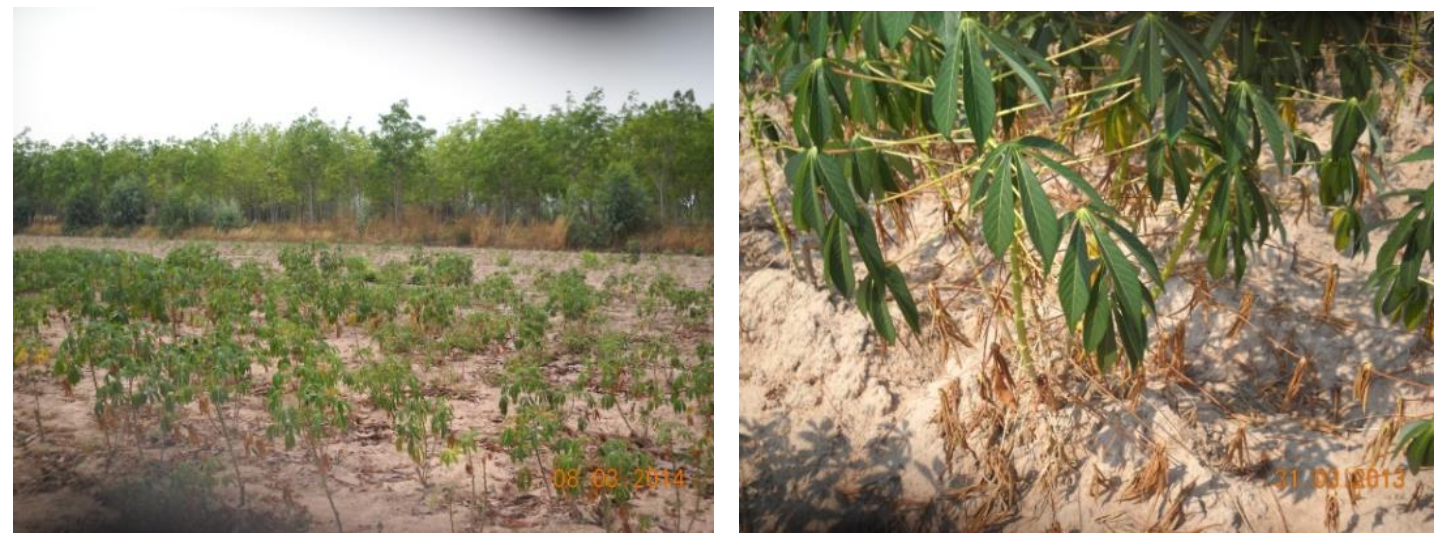

Figure 4. Leaves senescense of cassava during water stress at early growth stage, northeastern Thailand

Cassava is regarded as a relatively drought-tolerant crop as it reduces water use by following leaf area reduction and stomatal closure. However, water stress causes yield reduction, especially water stress during early growth stages. Polthanee and Srisutham (2017) studied supplementary irrigation for cassava planted in the late rainy season of Northeast Thailand. They reported that all supplementary irrigation water regimes (based on daily cumulative pan evaporation) increased the leaf area index and tuber yield of cassava versus no-irrigation (control) during the dry season (Table 5). This indicates that supplementary irrigation to the crop during the dry season can be attained leaf area index higher than that of no-irrigation which the crop experienced to water stress during the early growth stage. 
Table 5. Effects of each irrigation regime and variety on leaf area index and tuber yield of cassava planted in the late rainy season

\begin{tabular}{|c|c|c|c|}
\hline \multirow[t]{3}{*}{ Treatment } & \multicolumn{2}{|c|}{ Leaf area index } & \multirow[t]{3}{*}{ Tuber yield (t/ha) } \\
\hline & 120 & 240 & \\
\hline & \multicolumn{2}{|c|}{ - } & \\
\hline \multicolumn{4}{|c|}{ Variety across irrigation regime (V) } \\
\hline Huaybong-80 & 0.60 & 4.79 & $92.5 \mathrm{a}$ \\
\hline Rayong-11 & 0.57 & 5.38 & $60.6 \mathrm{~b}$ \\
\hline \multicolumn{4}{|c|}{ Irrigation regime across variety (I) } \\
\hline $\mathrm{I}-15,40 \mathrm{~mm}$ & $0.64 \mathrm{ab}$ & $5.45 \mathrm{a}$ & $79.2 \mathrm{ab}$ \\
\hline $\mathrm{l}-15,60 \mathrm{~mm}$ & $0.53 \mathrm{ab}$ & $4.84 \mathrm{ab}$ & $74.9 \mathrm{~b}$ \\
\hline $\mathrm{I}-30,40 \mathrm{~mm}$ & $0.67 \mathrm{a}$ & $5.77 \mathrm{a}$ & $85.6 \mathrm{a}$ \\
\hline $\mathrm{I}-30,60 \mathrm{~mm}$ & $0.65 \mathrm{a}$ & $5.59 \mathrm{a}$ & $54.6 \mathrm{c}$ \\
\hline $1-0$ & $0.43 c$ & $3.77 \mathrm{~b}$ & $51.1 \mathrm{c}$ \\
\hline \multicolumn{4}{|l|}{ F-test } \\
\hline $\mathrm{V}$ & ns & ns & $*$ \\
\hline I & $* *$ & $*$ & $* *$ \\
\hline $\mathrm{Vxl}$ & ns & ns & ns \\
\hline
\end{tabular}
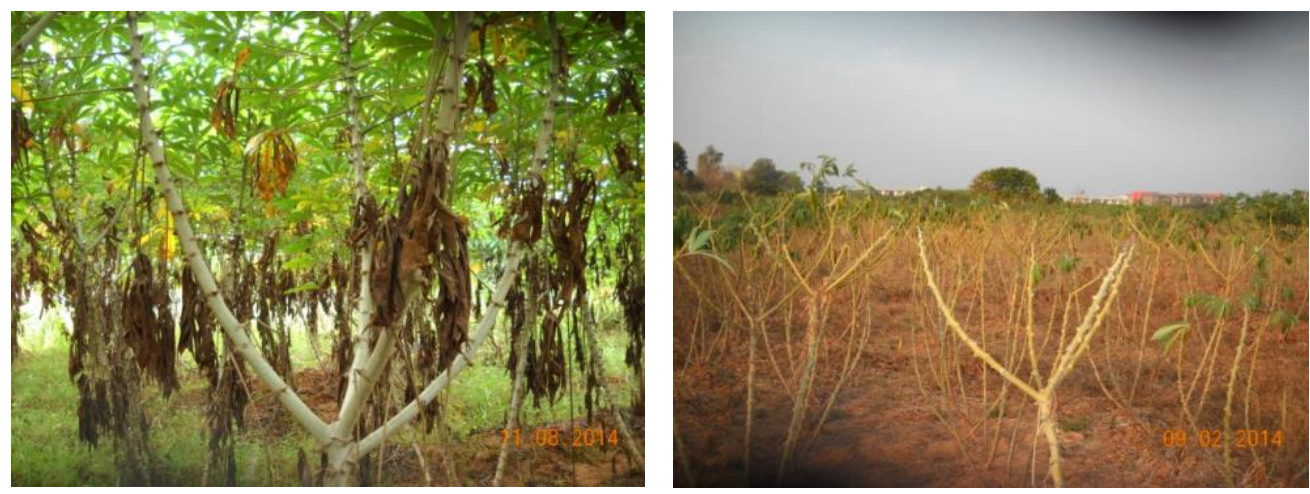

Figure 5. Leaves senescense of cassava during water stress at late growth stage, Northeast Thailand

In addition, Polthanee and Srisutham (2018) studied supplementary irrigation at different time (saving water), during the dry season for cassava planted in the late rainy season when the crop experienced to water stress during the early growth stage. They reported that supplementary irrigation water (based on daily cumulative pan evaporation value reached $40 \mathrm{~mm}$ the crop received $15 \mathrm{~mm}$ of water) from planting to 2 months after planting (MAP) or from 3 to 4 MAP significantly increased stem weight, leaf weight, root yield and starch content versus no-irrigation (control) during the dry season (Table 6). 
Table 6. Effects of drip irrigation at different times during the dry season on growth, yield and starch content of cassava planted in the late rainy season

\begin{tabular}{|c|c|c|c|c|}
\hline \multirow{2}{*}{ Treatment } & stem & leaf & \multirow{2}{*}{$\begin{array}{c}\text { Tuber yield } \\
\text { (t/ ha) }\end{array}$} & \multirow{2}{*}{$\begin{array}{c}\text { Starch content } \\
(\%)\end{array}$} \\
\hline & \multicolumn{2}{|c|}{ (gm/ plant) } & & \\
\hline \multicolumn{5}{|c|}{ Variety across irrigation regime (V) } \\
\hline Huaybong-80 & 2309.9 & 348.3 & $41.68 \mathrm{a}$ & 32.16 \\
\hline Rayong-11 & 2742.9 & 444.6 & $36.75 \mathrm{~b}$ & 30.96 \\
\hline \multicolumn{5}{|l|}{ Irrigation time (I) } \\
\hline Planting - 2 MAP & $2938.8 \mathrm{a}$ & $500.4 \mathrm{a}$ & $47.00 \mathrm{a}$ & $33.19 \mathrm{a}$ \\
\hline 3-4 MAP & $2865.6 \mathrm{a}$ & $379.8 \mathrm{~b}$ & $45.38 \mathrm{a}$ & $33.20 \mathrm{a}$ \\
\hline 5-6 MAP & $2278.5 b$ & $369.9 \mathrm{~b}$ & $38.94 \mathrm{ab}$ & $29.70 \mathrm{~b}$ \\
\hline No-irrigation (control) & $2016.6 \mathrm{~b}$ & $335.8 \mathrm{c}$ & $25.63 \mathrm{~b}$ & $30.16 \mathrm{~b}$ \\
\hline \multicolumn{5}{|l|}{ F-test } \\
\hline V & ns & ns & $*$ & ns \\
\hline I & $* *$ & * & $*$ & $*$ \\
\hline $\mathrm{V} \times \mathrm{I}$ & ns & ns & ns & ns \\
\hline
\end{tabular}

ns $=$ Not significant, Significantly different at $P \leq 0.05\left({ }^{*}\right)$ and $P \leq 0.01(* *)$, MAP $=$ Month after planting. Mean in the same column with different letters are significantly at $P \leq 0.05$ by LSD.

Sources: Adapted from Polthanee and Srisutham (2018)
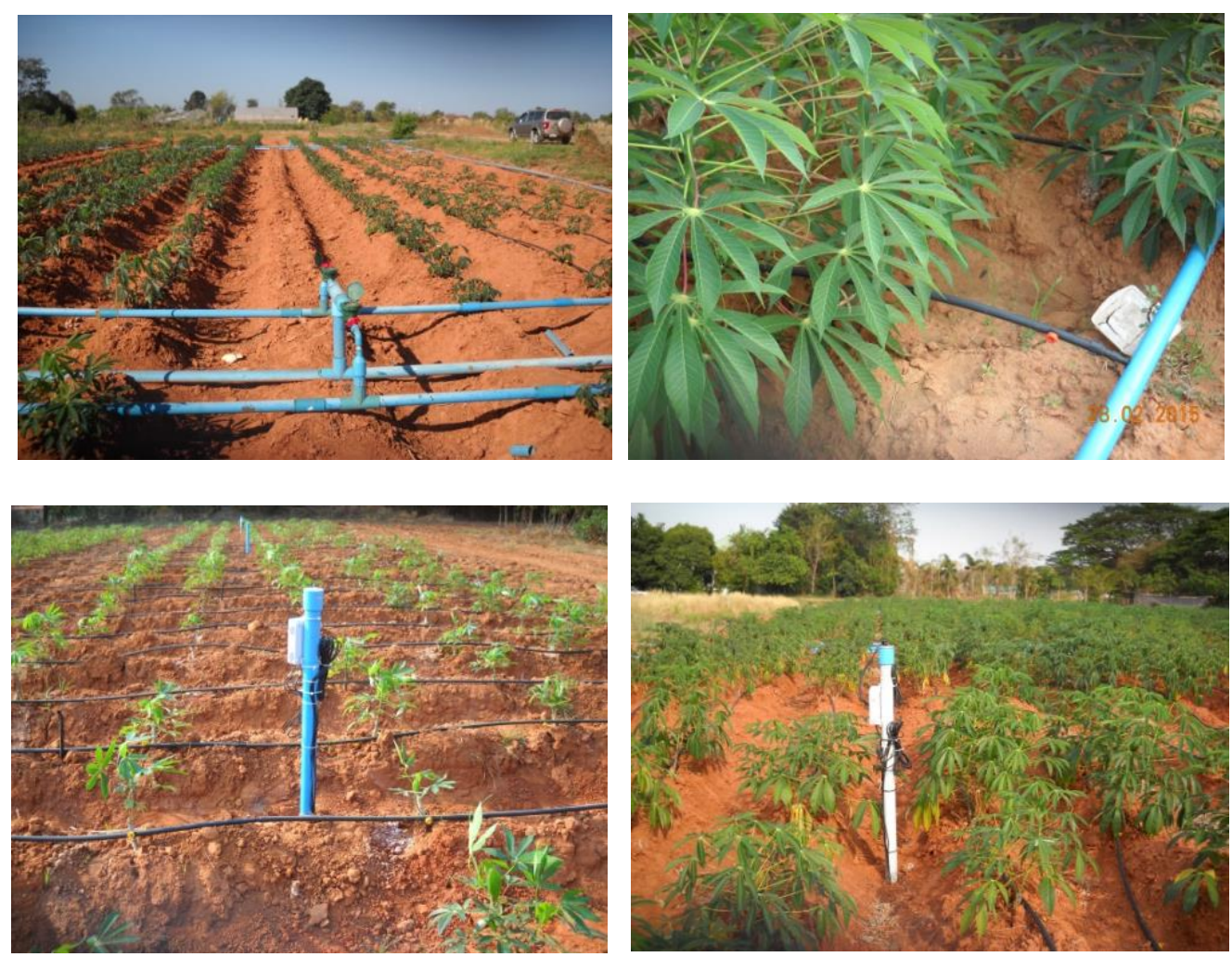

Figure 6. Supplementary by drip irrigation during the dry season

\subsection{Cassava a minor crop for additional farm income}

Cassava is generally found to be more resilient under harsher climatic conditions than other crops. Therefore, farmers cultivated cassava profitably as a second crop (rice-cassava) and intercrop (rubber+cassava) under rainfed conditions in Northeast Thailand. 
Rice is the major crop of farmers in Northeast Thailand. In general, farmers cultivate only once a year in the region, during times when the rainy season allows for its cultivation as a monoculture. During the dry season these rice field areas are used as cassava cultivation. Cassava is a drought-tolerant crop that can be grown after rice by 6-7 months harvest using residual soil moisture and early rainfall in the rainy season (Table 7). Therefore, the farmers earn additional farm income by growing cassava after rice instead of leaving the paddy fields to fallow in the dry season.

Table 7. Growth, yield and starch content of cassava at harvest (6 months), and net income of cassava grown after rice by farmers

\begin{tabular}{llllll}
\hline $\begin{array}{l}\text { Farmer/Paddy field } \\
\text { type }\end{array}$ & $\begin{array}{l}\text { Aboveground } \\
\text { biomass } \\
\text { (gm/plant) }\end{array}$ & $\begin{array}{l}\text { Storage root } \\
\text { (no./plant) }\end{array}$ & $\begin{array}{l}\text { Yield } \\
\text { (t/ha) }\end{array}$ & $\begin{array}{l}\text { Starch } \\
\text { content } \\
\text { (\%) }\end{array}$ & $\begin{array}{l}\text { Net income* } \\
\text { (US\$.) }\end{array}$ \\
\hline $\begin{array}{l}\text { Farmer A } \\
\quad \text { Upper paddy }\end{array}$ & 417.5 & 5.5 & 10.9 & 21.8 & 89 (0.16 ha) \\
$\quad \begin{array}{l}\text { Medium paddy } \\
\text { Farmer B }\end{array}$ & 583.9 & 6.8 & 18.4 & 20.3 & 530 (0.48 ha) \\
$\quad$ Medium paddy & 775.4 & 8.9 & 23.8 & 23.9 & 720 (0.48 ha) \\
\hline Mean & 592.4 & 7.1 & 17.7 & 22.0 & \\
\hline
\end{tabular}

* Net income over fertilizer cost. Source: Adapted from Polthanee et al. (2014a)

Polthanee et al. (2014b) studied cassava cultivars suitable for growing after rice in rainfed lowland areas. They reported that Rayong-7 cultivar produced the maximum fresh storage root yield, while the Rayong-72 gave the highest dry root yield (Table 8).

Table 8. Storage root number, fresh and dry storage root yield and starch content of different cassava cultivars grown after rice without irrigation in dry season

\begin{tabular}{|c|c|c|c|c|}
\hline \multirow[t]{2}{*}{ Cultivar } & \multirow{2}{*}{$\begin{array}{l}\text { Storage root } \\
\text { (no./plant) }\end{array}$} & \multicolumn{2}{|c|}{ Yield (t/ha) } & \multirow{2}{*}{$\begin{array}{l}\text { Starch content } \\
\text { (\%) }\end{array}$} \\
\hline & & Fresh & Dry & \\
\hline Rayong-7 & 7.0 & $28.2 \mathrm{a}$ & $723.8 \mathrm{ab}$ & 19.6 \\
\hline Rayong-11 & 6.3 & $21.3 \mathrm{ab}$ & $720.6 \mathrm{ab}$ & 23.7 \\
\hline Rayong-72 & 5.3 & $27.8 \mathrm{a}$ & $955.1 \mathrm{a}$ & 19.1 \\
\hline Kasetsart-50 & 4.8 & $23.2 \mathrm{ab}$ & $642.9 \mathrm{ab}$ & 25.9 \\
\hline Huaybong-80 & 6.8 & $19.2 \mathrm{~b}$ & $613.4 \mathrm{~b}$ & 25.7 \\
\hline F-test & ns & $*$ & $*$ & ns \\
\hline CV (\%) & 26.4 & 17.1 & 17.2 & 16.9 \\
\hline
\end{tabular}

ns $=$ Not significant, $*$ Significantly different at $P \leq 0.05$

Mean in the same column with different letters are significantly at $P \leq 0.05$ by LSD.

Source: Adapted from Polthanee et al. (2014b)
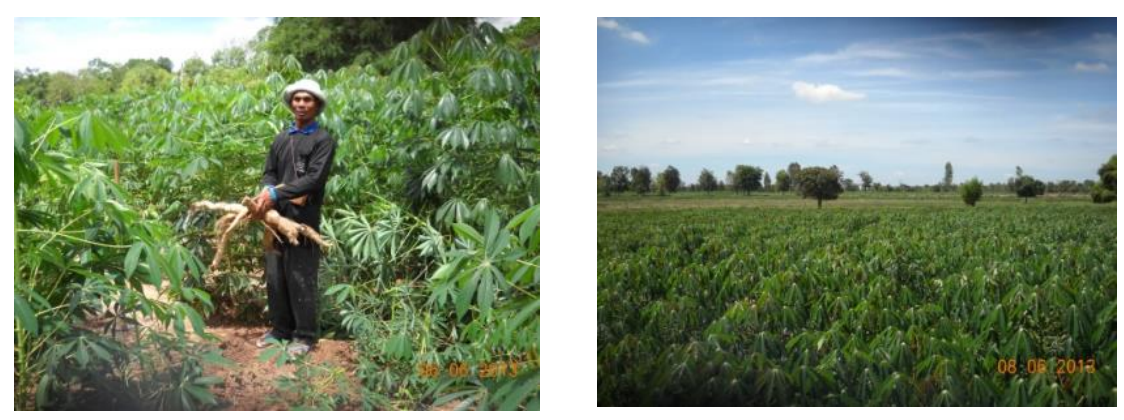

Figure 7. Cassava grown after rice without irrigation in dry season 
Rubber has a long time lag of about 6-7 years to provide farm income before tapping. Some farmers intercropped rubber with cassava during the immature phase of rubber. Polthanee et al. (2016b) reported that storage root yields obtained $24 \mathrm{t} /$ ha by crops sampled in the $4^{\text {th }}$ year of intercropping cassava with rubber in the farmer field, and providing cash income about 763 US\$/ha/year.
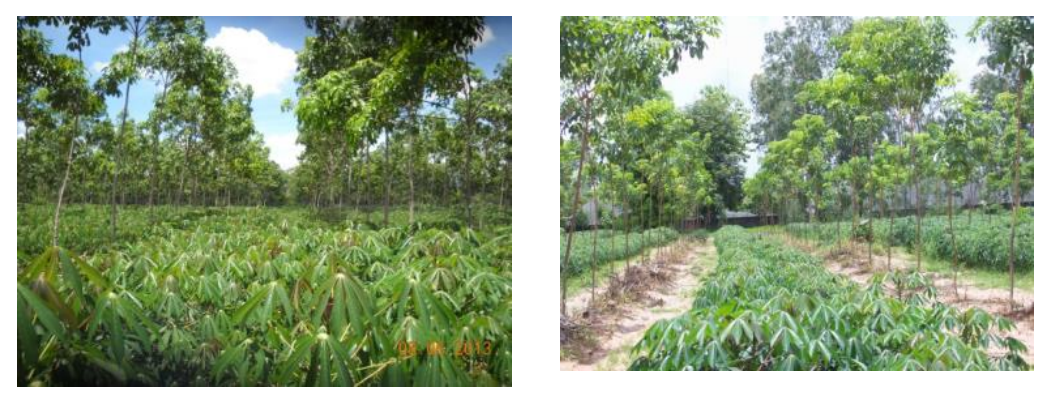

Figure 8. Rubber intercropped with cassava in the farmer's field, northeastern Thailand

Moreover, Polthanee and Promsena (2010) studied different cash crops including cassava intercropped in rubber plantations. They found that cassava intercropping generated an average net income over materials cost and variables cost (material cost + labour cost) at about 714 and 391 US\$/ha (Table 9).

Table 9. Yield, production cost, gross income and net income of cassava and peanut intercropped with rubber at 1 and 2 years after plantation

\begin{tabular}{llll}
\hline Item & First year & Second year & Average \\
\hline 1.Yield & & & \\
- Cassava (t/ha) & 22.4 & 24.8 & 23.6 \\
- Peanut (t/ha) & 1.6 & 1.2 & 1.4 \\
2.Material cost & & & \\
- Cassava (US\$./ha) & 172.1 & 172.1 & 172.1 \\
- Peanut (US\$./ha) & 173.2 & 173.2 & 173.2 \\
3.Labour cost & & & \\
- Cassava (US\$./ha) & 292.9 & 292.9 & 292.9 \\
- Peanut (US\$./ha) & 322.3 & 322.3 & 322.3 \\
4.Gross income & & & \\
- Cassava (US\$./ha) & 841.8 & 872.7 & 857.3 \\
- Peanut (US\$./ha) & 761.7 & 544.3 & 658.0 \\
5.Net income over material cost & & & \\
- Cassava (US\$./ha) & 667.9 & 759.2 & 713.6 \\
- Peanut (US\$./ha) & 588.5 & 381.1 & \\
6.Net income over material and labour & & & \\
cost & & & 391.3 \\
- Cassava (US\$./ha) & 375.0 & 407.6 & 162.5 \\
- Peanut (US\$./ha) & 266.2 & 58.8 & \\
\hline
\end{tabular}

Source: Adapted from Polthanee and Promsena (2010) 

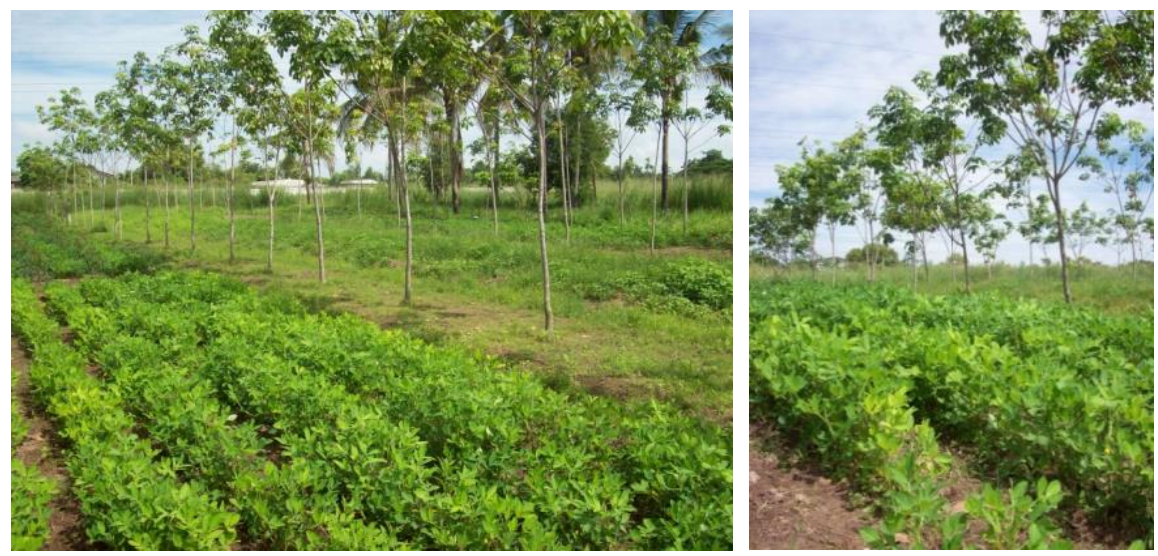

Figure 9. Rubber intercropped with peanut of researcher experiment
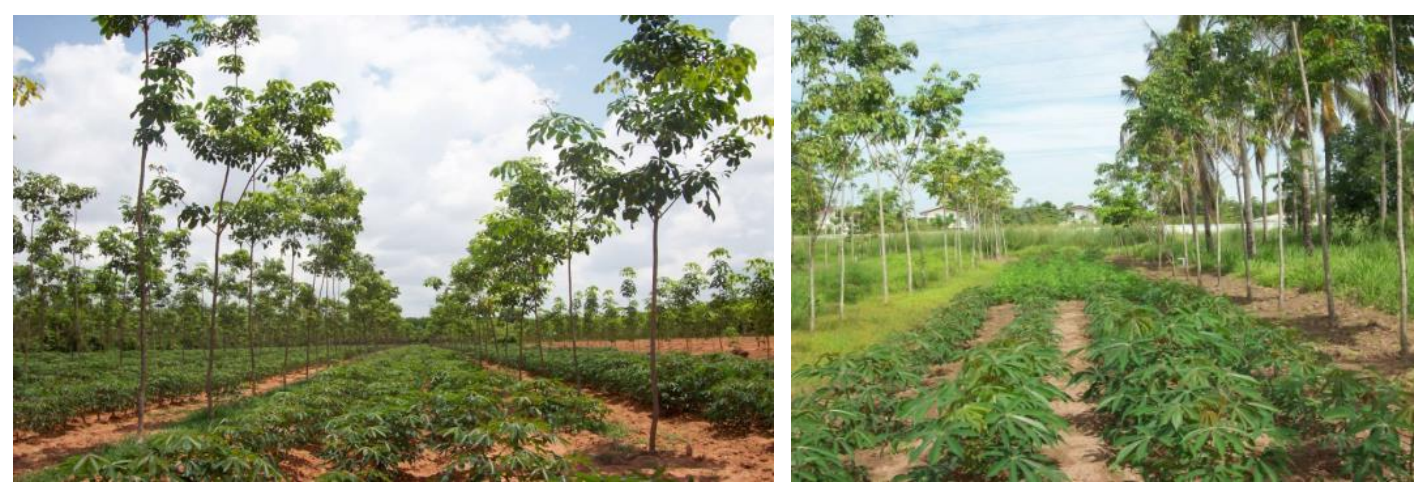

Figure 10. Rubber intercropped with cassava of researcher experiment

\section{Socioeconomic characteristics}

\subsection{Land and labor}

Most cassava farmers in Northeast Thailand are ethnically Thai, have their own land and land certificates. The average cassava cultivating area was about 2.46 ha, with an average farm labor of 2.87 persons (Ketkaewliang et al., 2015).

The Northeast Thailand landscape is predominantly of an undulating landform, which is divided into three types of land, namely upland field, upper paddy field and lower paddy field. In general, household labor cultivates crops grown under three types of land during a given year. Cassava is cultivated in upland fields while rice is grown in the paddy fields. Rice is a major crop of the smallholder farmers in Northeast Thailand. It plays an important role of food for home consumption, and the excess yield is sold for additional income. The first labor priority is allocated for rice production. In fact, cassava planting and harvesting time coincides with seasonal farm labor distribution and strategically does not overlap with rice cultivation (Figure 11). 


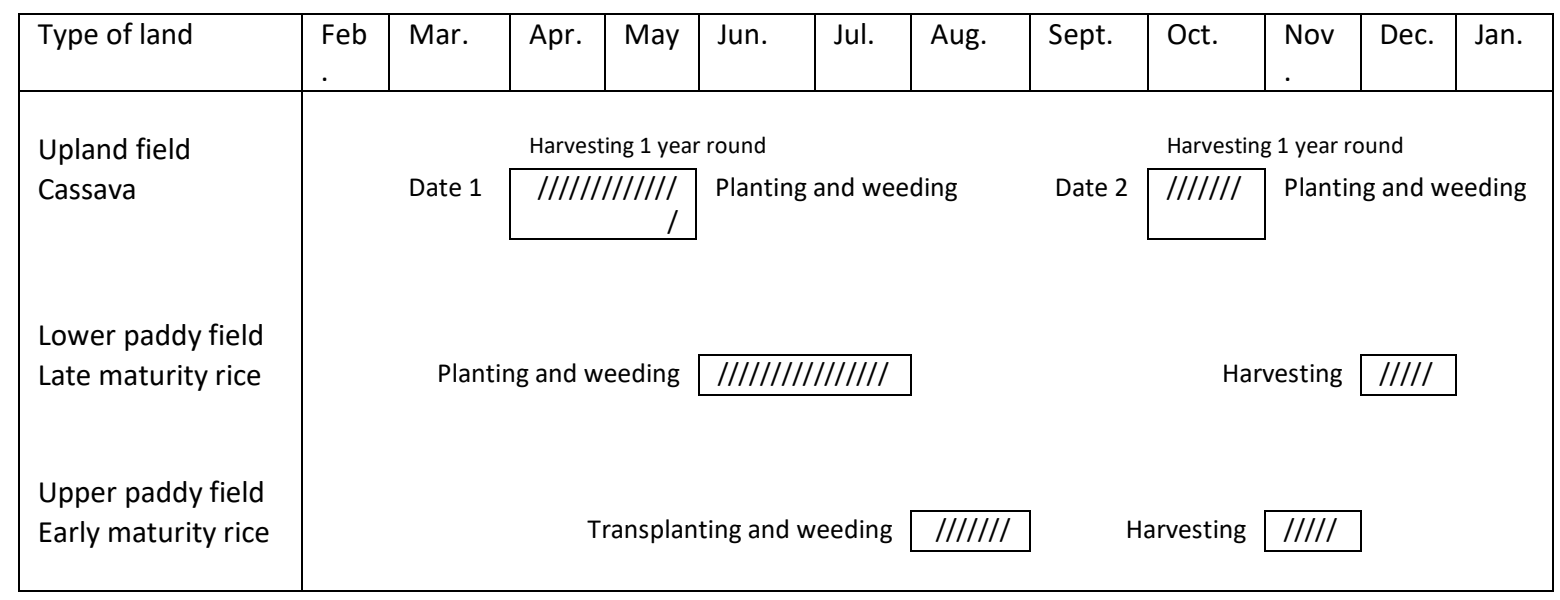

Figure 11. Seasonal distribution of labor for a farmer cultivating small plots on upland, lower paddy and upper paddy fields

\subsection{Case study of investment and income}

The profitability of cassava production in Namyuen district, Ubonratchatani province, Northeast Thailand is calculated based on primary yield and production cost/income price data collected during individual farmer interviews. This helps to provide a comparison between traditional farmer practices and improving practices through drip irrigation that is recommended by the researcher and shown in more detail in Table 10.

Table 10. Average production cost and income of cassava cultivation based on traditional practices under rainfed and improving practices under supplementary drip irrigation

\begin{tabular}{lcc}
\hline Category & Traditional practices (N=50) & Improving practices (N=50) \\
\hline Labor cost (US\$ per ha) & 496 & 662 \\
Materials cost (US\$ per ha) & 284 & 487 \\
Tuber yield (ton per ha) & 33 & 41 \\
Gross income (US\$ per ha) & 2078 & 2635 \\
Net income (US\$ per ha) & 1298 & 1486 \\
\hline
\end{tabular}

Note: Materials cost $=$ fertilizer, pesticides, gasoline

Source: Prawanne (2015)

The net income of traditional practices averaged 1,298 US\$/ha, while the net income of improving practices averaged 1,486 US\$/ha. Therefore, improving practices through drip irrigation increased net income over traditional practices 188 US\$/ha (15\%). Farmer in Nakornratchasima province practiced supplementary drip irrigation and earned a net income that averaged around 2,172 US\$/ha (Bannalai, 2016). However, farmers who adopted drip irrigation for supplementary water in the dry season were located in areas that could access underground water by pumping from tube wells.

\subsection{Marketing}

In general, cassava farmers sold their output immediately after harvest. Individual small farmers transport the tuber root product to cassava merchants who give a high price of tuber root located nearby their farm. The cassava price varies year to year (Table 11), depending on demand of the main trade partner from China. Moreover, Vietnam sold tapioca products at a lower price than that of Thailand also affecting price competitiveness and demand. 
Table 11. Cassava price by year, 2013-2017

\begin{tabular}{lccccc}
\hline Category & 2013 & 2014 & 2015 & 2016 & 2017 \\
\hline Farm gate price (US\$ per ha) & 67.7 & 70.3 & 68.7 & 51.3 & 48.4 \\
Tapioca chips price (US\$ per ha) & 222.6 & 231.9 & 233.5 & 197.4 & 183.9 \\
Tapioca pellet price (US\$ per ha) & 242.3 & 245.5 & 262.3 & 246.5 & 200.0 \\
Tapioca starch price (US\$ per ha) & 460.0 & 440.9 & 457.7 & 397.4 & 358.7 \\
\hline
\end{tabular}

Source: Adapted from Office of Agricultural Economics (2018)
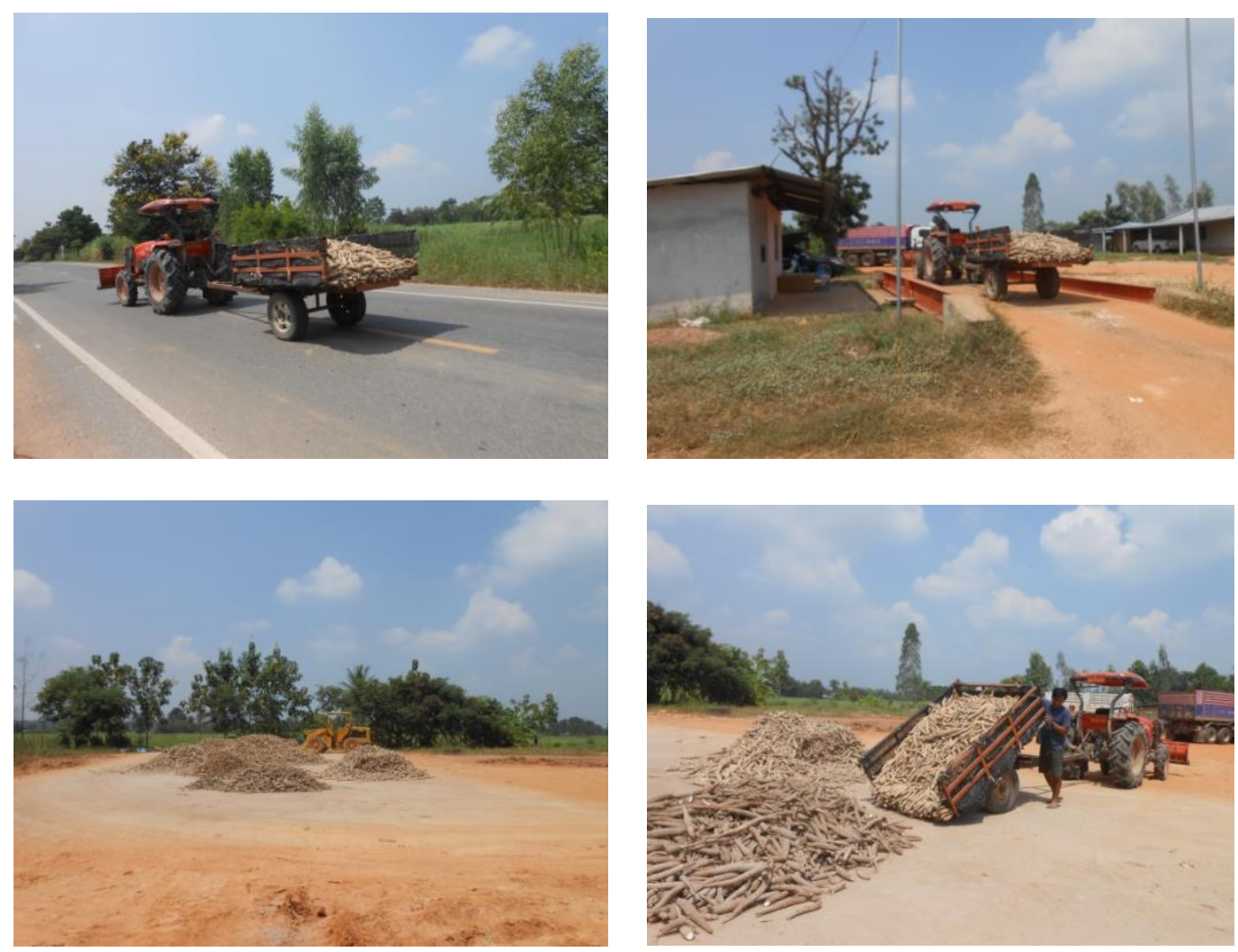

Figure 12. The tuber roots were loaded from farmer's cassava field to merchant for sell

Major markets for tapioca products are mostly in Asia. Tapioca chips export to China. Tapioca pellets export to Turkey and Japan. Tapioca starch exports to China, Indonesia, Taiwan and Malaysia. Modified starch exports to Japan, China, Indonesia and South Korea (Office of Agricultural Economics, 2018). The domestic demand of cassava is approximately 20 percent while 80 percent is for export. Cassava export values by year in Thailand is shown in Table 12.

Table 12. Cassava export values (million US\$) by year, 2013-2017 of Thailand

\begin{tabular}{rccccc}
\hline Year & $\begin{array}{c}\text { Tapioca chip } \\
\text { (million US\$) }\end{array}$ & $\begin{array}{c}\text { Tapioca pellet } \\
\text { (million US\$) }\end{array}$ & \multicolumn{2}{c}{ Cassava starch } & \multirow{2}{*}{ Total } \\
\cline { 4 - 5 } & 1274.7 & 13.1 & 1125.2 & Modified & \\
2013 & 1576.5 & 4.6 & 1324.3 & 646.4 & 3059.4 \\
2015 & 1673.2 & 9.4 & 1327.9 & 697.6 & 3603.0 \\
2016 & 1262.4 & 2.6 & 1290.2 & 691.8 & 3702.4 \\
2017 & 1180.6 & 7.6 & 1148.4 & 665.3 & 3240.5 \\
\hline
\end{tabular}

Source: Adapted from Office of Agricultural Economics (2018)

Cassava serves as an economic and social link. In general, there are twelve ceremonies 
practicing by the rural peoples every month in a year (Figure 13). These ceremonies can be divided into four purposes. (1) requesting the rainfall for coming on the right time, (2) requesting for good farm production, (3) requesting the happiness for those family members who have died and (4) enjoying entertaining after working hard.

As mentioned above, farmers prefer to plant cassava two times per year (early and late rainy season), to increase income. Cassava is harvested at the end of the dry season (March - April) providing cash to buy inputs such as chemical fertilizer for rice production. The second cassava harvest in the late rainy season (October - November), provides materials for ceremonies such as Bun Khaogam, Bun Koonlan and New year.

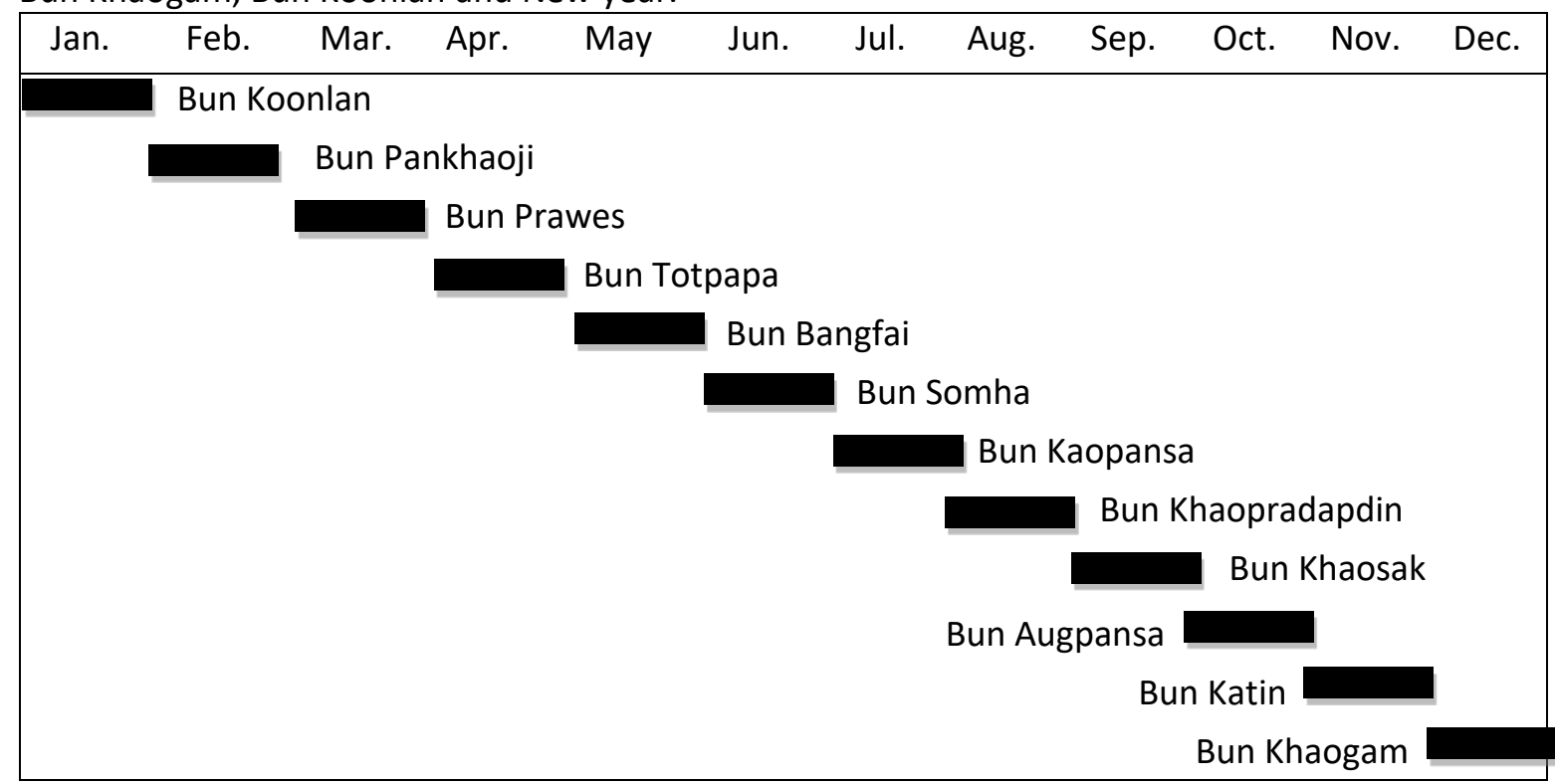

Figure 13. Annual calendar of family and village festival in Northeastern Thailand

\section{Conclusion}

A review of the literature on the role of cassava for smallholder farmers in Northeastern Thailand reveals that cassava will continue to be a suitable crop for cultivation in Northeast Thailand. The reasons are that the crop is better adapted to soil and climate characteristics of the region. In addition, cassava requires minimal care and less investment and crop response provides satisfactory yield. Breeding and selection is based on short growth duration variety and should be realized in the future for cropping intensification. Improving practices through supplementary drip irrigation can increase potential opportunities for cassava income in comparison with traditional practices that only receive rainfed conditions. However, although farmers can earn greater income from improving cassava practices it may still be unable to cover household living expenses for the whole year. At present, most of the farmers receive a total household income of about $60 \%$ from non-farm work income and the remaining $40 \%$ from farming. Therefore, although most farmers in the Northeastern region must seek income from migration in larger urban centers, this paper has shown that cassava plays an important role for supplemental income, especially at key times of the year. The important role that cassava plays in Northeastern Thailand is likely to continue in the future.

\section{References}

Alves, A.A.C. and Setter, T.L. (2000). Response of cassava to water deficit : leaf area growth and abscisic acid. Crop Science 40: 131-137. Doi : 10.2135/crop sci 2000.401131x.

Atichart, S., Worasatit, N., Srisatit, R. and Thummak. (2013). Study on variation of the rainy season 
period in the Northeast of Thailand. Khon Kaen Agric. J. 1: 346-351. (in Thai)

Bannalai, P. (2016). Study on investment of drip irrigation of cassava cultivation in Nakhonratsima province. A paper evaluation for promoting policy analysis position. Office of Agricultural Economics, Minitry of Agriculture and Cooperative, Thailand. (in Thai)

Connor, D.J. and Cock, J.H. (1981). Response of cassava to water shortage. II. Canopy dynamics. Field Crops Research 4: 285-296.

Department of Provincial Administration. (2016). Populations of 77 provinces in year 2016. https://www.m_society.go.th/article-attach/20414/20414/21054. (in Thai)

De Tafur, S.M., EL-Sharkwy, M.A. and Calle, F. (1997). Photosynthesis and yield performance of cassava in seasonally dry and semiarid environments. Photosynthetica 33: 229-257.

EL-Sharkawy, M.A. and Cock, J.H. (1984). Water use efficiency of cassava. I. effects of humidity and water stress on stomatal conductance and gas exchange. Crop Sci. 24: 297-502.

EL-Sharkawy, M.A. (1993). Drought-tolerant cassava for Africa, Asia, and Latin America: breeding projects work to stabilize productivity without increasing pressures on limited natural resources. Bioscience 43: 441-451.

EL-Sharkawy, M.A. (2007). Physiological characteristics of cassava tolerance to prolonged drought in the tropics: implication for breeding cultivars adapted to seasonally dry and semiarid environments. Brazilian. J. of Plant Physiol. 19: 257-286.

FAO. (2010). Why cassava. Food and Agriculture Organization of the United Nations Statistics Database. Available at : http://www.fao.org/ag/AGP/agpc/gcds/index_en.html.

Goto,S., Kumwagata, T., Konghakotte, P., Polthanee, A., Ishigooka, Y., Toritani, H. and Hasegawa, T. (2008). Characteristics of water balance in arainfed paddy field in northeast Thailand. Paddy Water Environ. 6: 153-157.

Howeler, R.H. (2002). Agronomic practices for sustainable cassava production in Asia. In: Cassava Research and Development in Asia. Proceedings of the Seventh Regional Workshop hold in Bangkok, Thailand, October 28- November 1, 2002. 288-314 pp.

Idhipong, S., Pong-sed, A. Maolanont, T., Wani, S.P., Rego, T.J. and Pathak, P. (2012). Improved crops and cropping systems for rainfed Northeast Thailand. In: Community watershed management for sustainable intensification in Northeast Thailand (Siehas P. Wani, P. Pathak and K.L. Sahrawet, eds.). ICRAT, Patunchew 502324, Andra Pradesh, India. 92-131 pp.

Ike, I.F. and Thurtell, G.W. (1981). Response of indoor grown cassava to water deficits and recovery of leaf water potential and stomatal activity after water stress. J. Exp. Bot. 32: 1029-34.

Lacombe, G., Polthanee, A. and Trebuil, G. (2017). Long-term change in rainfall distribution in Northeast Thailand: will cropping systems be able to adapt? Cah. Agric. Dol: 10.1051/cagri/2017006.

Ketkaewliang, C., Yooprasert, B. and Tangwiwat, P. (2015). Extension needs in cassava production of farmers in Erawan District, Loei. In : Proceedings of the $5^{\text {th }}$ STOU Graduate Research Conference. 5-12 pp.

Molina, J.L. and EL-Sharkawy, M.A. (1995). Increasing crop productivity in cassava by fertilizing production of planting material. Field Crop Res. 44: 151-157.

Nedunchezhiyan, M., Naskar, S.K., Ranasingh, N. and Saurabh, A. (2006). A new food crop for dry farming-cassava. Orissa. Review. 41-42.

Noble, A.D. (2005). Sustainable management of problem soils: studies from Northeast Thailand. Proceedings of the mid-tern workshop on integrated management for sustainable use of low fertility and salt-affected soils in rainfed agriculture. FAO Project TCP/THA/2906, 18-21 April 2005, Khon Kaen, Thailand. 243-255 pp.

Office of Agricultural Economics. (2017). Agricultural Statistics of Thailand. Production Year 20092017. (in Thai)

Office of Agricultural Economics. (2018). Situation and trend of an important agricultural products in Thailand. Year 2018. (in Thai) 
Polthanee, A. (1990). Physical, biological and socio-economic conditions in technology transfer of field crops before rice in Northeast Thailand. In: Proceeding the $7^{\text {th }}$ Thailand National Farming Systems. p. 565-578.

Polthanee, A. and Promsena, K. (2010). Effect of cropping systems in intercropping with rubber on rubber growth and economic return. J. Sci. Technol. 29(3): 281-289.

Polthanee, A. and Promkambut, A. (2014). Impact of climate change on rice-based cropping systems and farmers' adaptation strategies in Northeast Thailand. Asian J. of Crop Sci. ISSN 19947879/DOI:10.3923/ajcs.2014.

Polthanee, A.,Promkhumbut, A. and Bamrungrai, J. (2014a). Drought impact on rice production and farmers' adaptation strategies in Northeast Thailand. International J. of Environmental and Rural Development. 5-1: 45-52.

Polthanee, A., Janthajam, C. and Promkhambut, A. (2014b). Growth, yield and starch content of cassava following rainfed lowland rice in Northeast Thailand. International J. Agric. Res. 9(6): 319-324.

Polthanee, A. and Manuta, P. (2015). Effect of stake priming with nutrient solution on growth and yield of cassava grown under greenhouse and field conditions. Khon Kaen Agr. J. 43(2): 379386.

Polthanee, A. and Bamrungrai, J. (2016). The effects of stake priming and planting method on early growth of cassava grown under greenhouse conditions. Naresuan Univ. J. Sci. Technol., 24:5664.

Polthanee, A.,Taboonmuang, R. and Manaonok, J. (2016a). Root yield and nutrient removal of four cassava cultivars planted in early rainy season of Northeastern Thailand. Asian J. of Crop Sci. ISSN 1994-7879/DOI: 10.3923/ajcs.2016.

Polthanee, A.,Promkhumbut, A. and Khamla, N. (2016b). Seeking security through rubber intercropping : A case study from northeastern Thailand. KKU Research J. 21(3): 1-11.

Polthanee, A. and Wongpichet, K. (2017). Effects of planting methods on root yield and nutrient removal of five cassava cultivars planted in late rainy season in Northeastern Thailand. Agricultural Science 8: 33-45.

Polthanee, A. and Srisutham, M. (2017). Supplementary irrigation for cassava planted in the late rainy season of Northeastern Thailand. Asian J. Crop Sci. ISSN 1994-7879 DOI: 10.3923/ajes.2017. 1-9.

Polthanee, A. (2018). Effects of duration storage on cassava stakes germination at different cultivars (Unpublished)

Polthanee, A. and Srisutham, M. (2018). Growth and yield of cassava as influenced by drip irrigation at different times during dry season in Northeastern Thailand (Unpublished).

Prawanne, S. (2015). An analysis of financial feasibility for investment in drip irrigation system for planting cassava production: A case study of Nam Yuen District, Ubon Ratchtani. Indepent Study, Master of Economics, Sukhothai Thammathirat Open University, Thailand.

Reddy, M.V.B., Arul, J., Angers, P. and Coutue, L. (1999). Chitosan treatment of wheat seeds induces resistance for fusorium graminearum and improves seed quality. J. of Agric. And Food Chem. 47: 1208-1212.

Royal Irrigation Department. (2008). Data on Environmental Resources Thailand. eaneo.nesdb.go.th. (in Thai)

Survey Division. (1996). Soil distribution in northeastern Thailand. Land Development Department and Survey Division, Ministry of Agriculture and Co-operatives.

Tongpoonpol, S., Pongkanchana, A. and Seehaban, P. (2012). Baseline characterization of Tad Fa watershed, Khon Kaen Province, Northeast Thailand. International Crop Research Institute for the Semi-Arid Tropics, Andhra Pradesh, India. 1-29.

Wilson, L.A. (1997). Root crops. In: Ecophysiology of Tropical Crops, (Paulo de T. Alvin and T.T. Koslowski, eds.). Academic Press New York San Fancisco London. 187-233 pp. 